\title{
Effect of the magnetotherapy in the regeneration after tenotomy in animals magnetotherapy in the regeneration
}

\author{
Adrian Guilhermo Carrillo Grimaldo ${ }^{1}$, Rodrigo Marcel Valentim da Silva², Débora Antunes Pousa Bezerra ${ }^{3}$, \\ Luíza Batista Lima ${ }^{3}$, Artur Dantas Freire ${ }^{4}$, Isafran Emanuelle dos Santos ${ }^{4}$, Marcelo Alejandro Senneke ${ }^{5}$, \\ Patrícia Froes Meyer ${ }^{6}$
}

\begin{abstract}
Background: The Achilles tendon is the largest and most resistant tendon in the human body, being one of the most common areas of overload injury among athletes. The rupture occurs more frequently in football athletes, running and jumping, because these activities cause a great stress on the tendon during eccentric muscle contraction of the sural triceps. Among the different physiotherapy resources used to repair tendon injuries, there is magnetotherapy, which is a feature that uses a pulsatile electromagnetic field, a suggested inducer of the acceleration of regeneration. Objective: To investigate the effects of magnetotherapy on the organization of collagen and elastic fibers and inflammatory process induced in different days and phases of the healing process of Achilles tendon injury in rats. Method: This study is a randomized controlled trial. Thirty female Wistar rats were randomly divided into 5 groups (each with $n=6$ ), submitted to tenotomy by transverse shear in the middle third of the right Achilles tendon, except for group 1, which was control group without injury, sacrificed on day 14. Group 2, control with injury, sacrificed on day 7; group 3 was treated and received 5 pulsed electromagnetic field (PEMF) applications from $24 \mathrm{~h}$ post injury and sacrificed on day 7; group 4, control with injury and sacrificed on day 14; and group 5 received 12 PEMF applications from $24 \mathrm{~h}$ post injury and sacrificed on day 14 . The parameters used were $20 \mathrm{mT}$, $50 \mathrm{~Hz}$ and 30 minutes of application in each session, using the Magnetherp ${ }^{\circledR} 330$ digital device (Meditea ${ }^{\circledR}$ ). At the end of treatment, a histological study was performed to evaluate the amount of collagen and elastic cells and fibers and to compare the degree of organization of collagen fibers. Results: G - 3, compared to its control G - 2 showed lower acute inflammatory response; G - 5 did not show acute and chronic inflammation and possessed an accelerated process of repair without fibrosis, unlike its control. Conclusion: The magnetotherapy decreased the signs of inflammation in the acute phase, accelerated the repair process with the onset of fibrosis in 7 days; and at 14 days the tendon tissue was healed, with organizing fibrosis, without acute or chronic inflammation.
\end{abstract}

Keywords: Achilles Tendon; Tenotomy; Physiotherapy; Magnetic Field Therapy.

\section{INTRODUCTION}

Tendons are the structures that connect skeletal muscles to bones and are formed by fibrous cords of connective tissue, consisting basically of longitudinal bundles of type I and III collagen fibers, lymphocytes and fibroblasts ${ }^{(1)}$. Any change in tendon structure is called tendinopathy. This pathology is very common in the clinical practice of physical therapy and is usually associated with overuse, mainly due to improper practice or lack of preparation for running ${ }^{(2)}$. The Achilles tendon is the largest and most resistant tendon in the human body, being one of the most common areas of overload injury among elite and recreational athletes ${ }^{(3)}$. Its rupture occurs more frequently in soccer, running and jumping athletes, especially in men from the third to the fifth decade of life, as these activities cause great stress on the tendon during the eccentric muscle contraction of the sural triceps. Repetitive microtrauma and tendon overloads induce partial or total rupture, which is preceded by inflammation and degenerative changes and leads to reduced blood flow with consequent local hypoxia. Due to the low vascularization of the tendon tissue, the repair process is limited, receiving its blood supply directly from the perimysium, periosteum, and in the vessels of the paratendon ${ }^{(4,5)}$. After an injury, the tendon repair process can be divided into three sequential phases called inflammatory, proliferative or fibroblastic and remodeling. The first phase of initiation after injury ends for one turn of the day when then a proliferative phase begins. The remodeling process lasts around four weeks with collagen alignment along the tissue ${ }^{(6)}$.

Address for correspondence: Adrian Guillermo Carrillo Grimaldo Palomas\#7, Fracc los pájaros, Santiago de Querétaro, México. e-mail: direccion@educacont.mx

1. Fisioactiv Queretaro Qro México, Santiago de Querétaro, México.

Full list of author information is available at the end of the article.

Financing Support: There was no financial supoort.

Submission date 22 November 2018; Acceptance date 16 January 2019; Publication date 21 December 2019

Institution: Fisioactiv in Queretaro Qro Mexico. 
Treatment protocols for Achilles tendon rupture are constantly modified. Despite several studies, there is no consensus on its treatment capacity and one can have two approaches: conservative and surgical. Physiotherapy is within conservative treatments which prevent reconstructive surgery ${ }^{(2,5)}$. Among the different electrothermophototherapeutic resources of physiotherapy that are used in the treatment of tissue repair of the tendon injury, it is suggested the use of magnetotherapy, which uses a pulsatile electromagnetic field that induces the formation of new electromagnetic fields perpendicular to its place of incidence ${ }^{(7)}$. Electromagnetic current causes deviations of particles with moving electric charges, production of induced currents, piezoelectric effect on bones and collagen tissue and increased solubility of substances. At the cellular level normalizes membrane potential and stimulates cell metabolism. At tissue level is a potent metabolic stimulator of cells, tissues and organs, acting as anti-inflammatory and analgesic ${ }^{(8)}$. Low-frequency pulsed electromagnetic field (PEMF) therapy is a non-invasive, safe and easily manipulated method and can be applied to a variety of conditions characterized mainly by pain, inflammation and regeneration. The PEMF generates biological effects in organisms, systems and organs, however, studies on these effects are still inconsistent ${ }^{(9)}$. Magnetotherapy is a commonly used resource in clinical practice in many countries, however there are few studies that demonstrate its physiological effects on tendon injuries. Thus, the main objective of this study was to investigate the effects of magnetotherapy on animal induced tenotomy, with the specific objectives of identifying its effects on inflammatory cells and tissue healing; evaluate the organization of collagen and elastic fibers in the tendon tissue.

\section{METHODS}

The study was characterized as a randomized controlled experimental. It was submitted and approved by the Animal Research Ethics Committee with protocol number 012/2013, and follows the animal research standards of SBCAL - COBEA (Sociedade Brasileira de Ciência em Animais de Laboratório).

\section{POPULATION AND SAMPLE}

The research population consisted of 30 female Wistar rats, with weight between 192g and 268,50g. The animals were kept during the experimental protocols in the Potiguar University (UnP) Animal Science Laboratory and surgical practice laboratory, with temperature between 22.0 to 27.0 Celsius degree and controlled lighting, minimum noise, same biological cycle with lighting period of 12 light hours and 12 dark hours, confined in individual cages lined with sawdust, where they received water and feed "ad libitum", and the therapy was performed in the afternoon shift.

\section{RESEARCH INSTRUMENTS}

The instruments used were Luer Slip ${ }^{\circledR}$ Disposable Syringe, Descarpack ${ }^{\circledR}$ needle, Standard ${ }^{\circledR}$ procedure gloves, Embramed ${ }^{\circledR}$ scalpel and the Magnetherp ${ }^{\circledR} 330$ magnetotherapy digital device (brand Meditea ${ }^{\circledR}$ ).

\section{PROCEDURES}

The animals were randomly divided into 5 groups (Table 1 ), observing the period from $24 \mathrm{~h}$ to 14 days, according to the healing period, totaling 6 animals per group.

Initially, all animals were weighed and subsequently anesthetized with Tiletamine hydrochloride and Zolazepam hydrochloride $\left(\right.$ Zoletil $^{\circledR} 50$ ), and $1.5 \mathrm{ml}$ of the solution was administered to each animal. Then manual trichotomy was performed, followed by antisepsis with antiseptic aqueous chlorhexidine in the posterior tibial region of the right posterior limb. A longitudinal incision (Figure 1A) was made on the skin over the tenotomy area in the middle third of the calcaneal tendon. For tendon fixation, two insulin needles were used between the calcaneal insertion and the myotendineal junction (Figure 1B), where the transverse shear total tenotomy was performed (Figure 1C) using scalpel blade 11 . Then the two parts of the tendon were sutured with 4.0 absorbable cotton thread (Figure 1D), followed by suturing the skin with the same thread, with no subsequent immobilization of the follow-up. The animals received Dipyrone Sodium drops $500 \mathrm{mg} / \mathrm{ml}$ (Lab. Medley ${ }^{\circledR}$ ) dissolved in water for analgesia during their recovery, balanced feed and were kept in separate and sanitized cages with 12-hour light and dark cycle illumination.

During 24 hours, the therapy with the magnetotherapy was started in the treated group in the segment, using the parameters of $20 \mathrm{mT}$ (milli Tesla), $50 \mathrm{~Hz}$ and 30 minutes of application time in each session, using the Magnetherp ${ }^{\circledR}$ 330 digital device (brand Meditea ${ }^{\circledR}$ ). In order to perform the treatment without anesthetizing the animal, an adaptation was made using a restraint to keep the rat within the electromagnetic field. During the research were followed the application schedules, mentioned above, in the respective animals. At the end of treatment, a histological study of the different groups was performed.

Table 1. Group distribution

\begin{tabular}{clc}
\hline GROUP & & Euthanasia \\
\hline G-1 & Control without lesion & 14 days \\
G-2 & Control with lesion & 7 days \\
G-3 & Treated with magnetotherapy (5 applications) & 7 days \\
G-4 & Control with lesion & 14 days \\
G-5 & Treated with magnetotherapy (12 applications) & 14 days \\
\hline
\end{tabular}




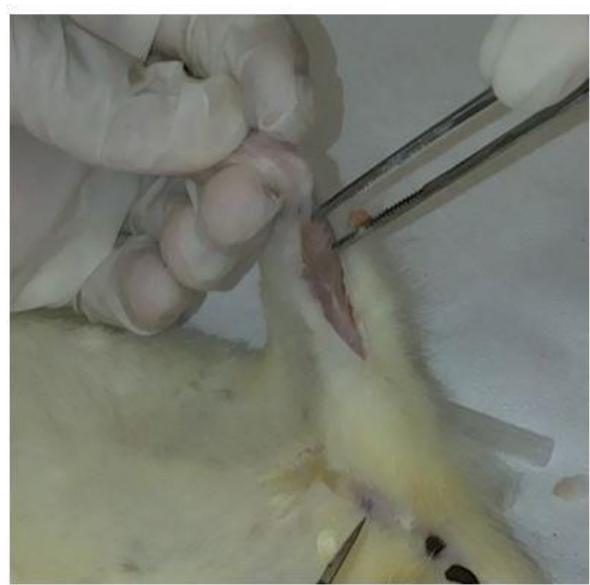

A

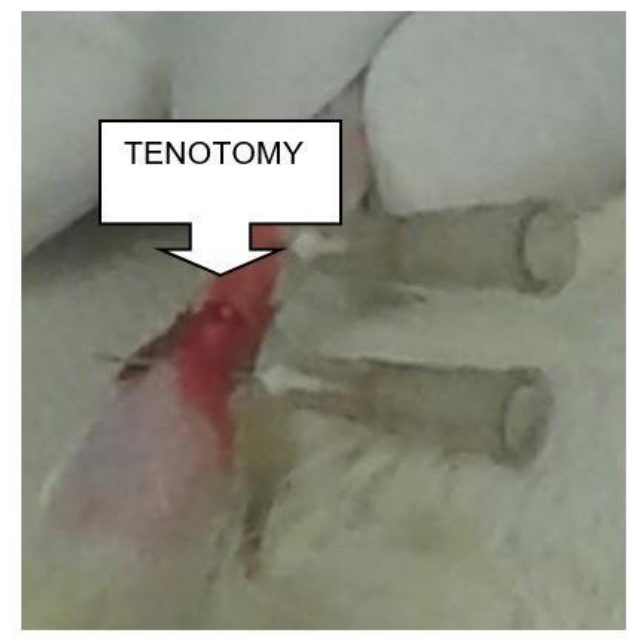

C

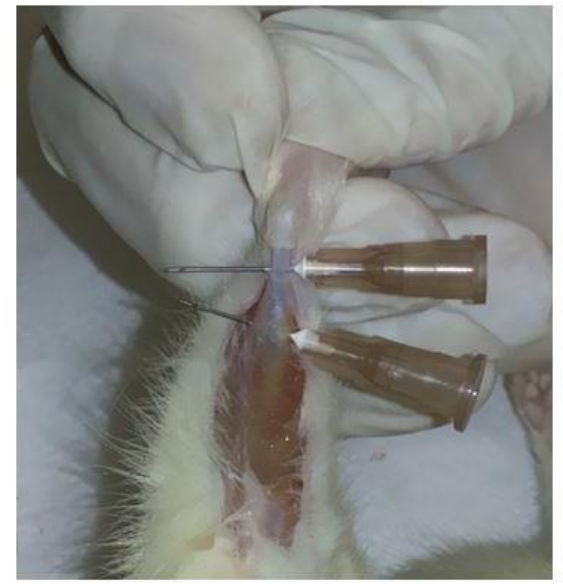

B

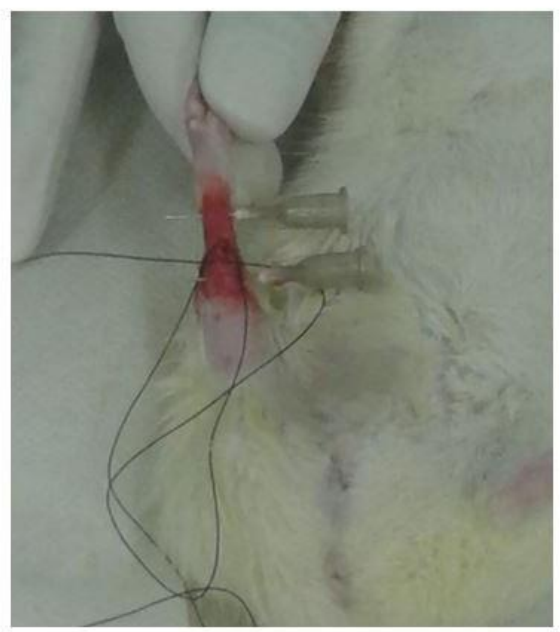

D

Figure 1: Surgical Technique.

Note: A: longitudinal incision for tendon exposure. B: Tendon fixation with insulin needles. C: Total tenotomy of the tendon by transverse shear. D: Tendon suture.

After collection, the biological fragment was placed in $10 \%$ formaldehyde and sent to the UnP Histology laboratory. After this procedure, the pieces were dehydrated through three alcohol passes lasting one hour each. Then, the diaphanization phase was performed through three passes of Xilol ${ }^{\circledR}$ during 10 minutes each. Then, the inclusion process was initiated by immersing the biological tissue in paraffin heated at $65 \circ \mathrm{C}$ in three one-hour passages each fragment. After the paraffin hardened, the fragment was taken to the microtome and cut into tapes three to five microns thick. The tapes were placed in a water bath at $35^{\circ} \mathrm{C}$ so that they could be fixed to the slide. Once ready, the slides were placed in the oven at $65 \circ \mathrm{C}$ for drying, followed by the Hematoxylin and Eosin (HE) staining battery process to perform analysis through a histopathological study.

\section{DATA ANALYSIS}

After making the slides, they were blindly examined by three pathologists under an Olympus optical microscope and microphotographs were taken with a digital camera attached to the microscope, showing the effect of treatment in the different groups on the collagen and elastic fibers.

\section{RESULTS}

The results of the histological study of all Achilles tendons are shown in Table 2, distribution of histological findings.

When analyzing this table it can be observed that $\mathrm{G}-3$, when compared with its control, G - 2, presented lower acute inflammatory response. Analyzing the groups $G-4$ and $G-5$, it can be noticed that the last one did not present acute and chronic inflammatory process, unlike its control 
Table 2. Distribution of histological findings.

\begin{tabular}{|c|c|c|c|c|c|c|c|}
\hline & Groups & Acute I.R. & Chronic I.R. & GC & Fibroses & Col & REP \\
\hline & G-1 & & & & & & \\
\hline & $\mathrm{R}-1$ & - & - & - & - & - & - \\
\hline & $\mathrm{R}-2$ & - & - & - & - & - & - \\
\hline \multirow[t]{7}{*}{ Control without injury (Sac. 14 days) } & $\mathrm{R}-3$ & - & - & - & - & - & - \\
\hline & $\mathrm{R}-4$ & - & - & - & - & - & - \\
\hline & R-5 & - & - & - & - & - & - \\
\hline & $\mathrm{R}-6$ & - & - & - & - & - & - \\
\hline & G-2 & & & & & & \\
\hline & $\mathrm{R}-1$ & +++ & - & - & - & - & - \\
\hline & $\mathrm{R}-2$ & +++ & - & - & ++ & - & - \\
\hline \multirow[t]{7}{*}{ Control with injury (Sac. 7 days) } & $\mathrm{R}-3$ & +++ & - & - & ++ & - & - \\
\hline & $\mathrm{R}-4$ & +++ & - & - & ++ & - & - \\
\hline & R-5 & +++ & - & ++ & ++ & - & - \\
\hline & R-6 & +++ & - & ++ & ++ & - & - \\
\hline & G-3 & & & & & & \\
\hline & $\mathrm{R}-1$ & + & - & - & - & - & ++ \\
\hline & $\mathrm{R}-2$ & - & ++ & - & ++ & - & - \\
\hline \multirow[t]{7}{*}{ Treated with PEMF 5 applic. (Sac. 7 days) } & $\mathrm{R}-3$ & - & ++ & - & ++ & - & - \\
\hline & $\mathrm{R}-4$ & - & - & - & +++ & - & - \\
\hline & R-5 & ++ & - & ++ & ++ & - & - \\
\hline & R-6 & - & - & - & +++ & - & - \\
\hline & $G-4$ & & & & & & \\
\hline & R-1 & + & + & - & - & ++ & ++ \\
\hline & $\mathrm{R}-2$ & + & + & - & ++ & - & +++ \\
\hline \multirow[t]{7}{*}{ Control with injury (Sac. 14 days) } & $\mathrm{R}-3$ & - & - & - & ++ & - & ++ \\
\hline & $\mathrm{R}-4$ & - & ++ & - & ++ & - & ++ \\
\hline & R-5 & - & ++ & - & ++ & - & ++ \\
\hline & $\mathrm{R}-6$ & - & ++ & - & - & - & ++ \\
\hline & G- 5 & & & & & & \\
\hline & R-1 & - & - & - & - & - & +++ \\
\hline & $\mathrm{R}-2$ & - & - & - & - & - & +++ \\
\hline \multirow[t]{4}{*}{ Treated with PEMF 12 applic. (Sac. 14 days) } & $\mathrm{R}-3$ & - & - & - & - & - & ++ \\
\hline & R-4 & - & - & - & - & ++ & +++ \\
\hline & R-5 & - & - & - & - & - & +++ \\
\hline & R-6 & - & - & - & - & - & +++ \\
\hline
\end{tabular}

Note: IT: Intact tendon; Acute I.R.: Acute Inflammatory Reaction; Chronic I.R.: Chronic Inflammatory Reaction; GC: Giant cells; Col: Collagenisation; REP: Repair; -: Absent; +: mild, ++: moderate; +++: high.

that still has moderate chronic inflammatory process. Also in these two groups, it is observed that the group treated with magnetotherapy has an accelerated repair process, without fibrosis, and although its control group also has moderate repair, it has moderate fibrosis. Comparing the groups treated with magnetotherapy, it is noted that with 5 applications, the animals, even with little acute inflammatory reaction, still had moderate and intense fibrosis and few repair cells, unlike the group that received 12 applications, which do not have fibrosis and the repair process is accelerated. Figure 2, which is a sample from the uninjured control group ( $G-1)$, shows the insertion of the triceps sural muscle with the calcaneal tendon intact, without the presence of injury, inflammatory cells or repair process. 
Figure 3, Photo A (G - 2: control with 7 days injury) shows an acute inflammatory process throughout the tendon surface, with more evidence near the suture and the presence of large edema in the region. In Photo B ( $\mathrm{G}-2$ ), when the image is increased by $400 x$, granulation tissue and polynucleated cells can be observed, which characterizes an intense inflammatory process. When Photo C (G - 3: 5 PEMF applications) is analyzed, although chronic inflammatory process and fibrosis are still

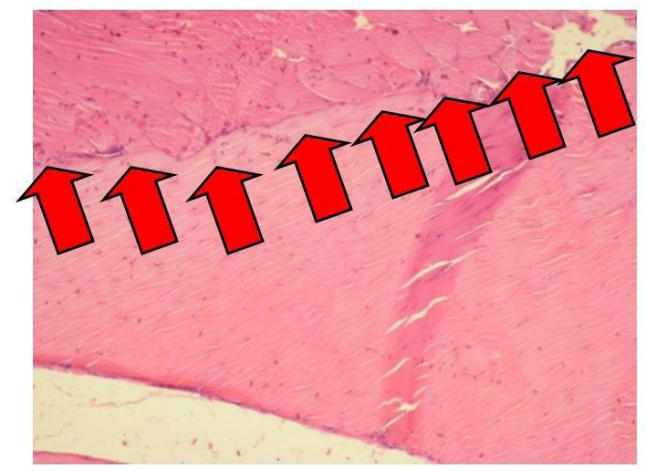

A

Figure 2: Sample from the uninjured control group Photomicrograph, 100x, HE).

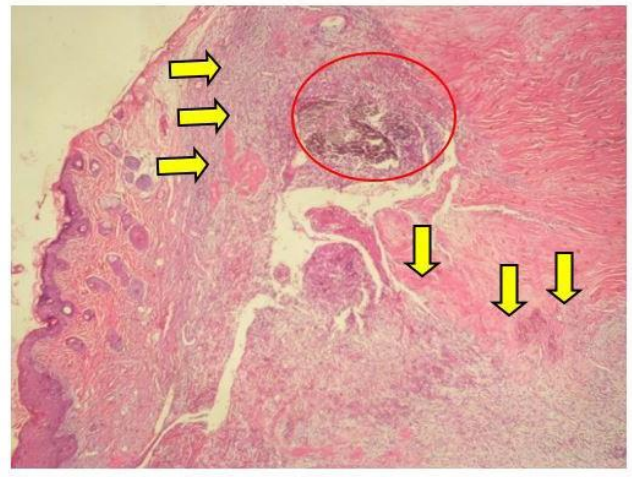

A

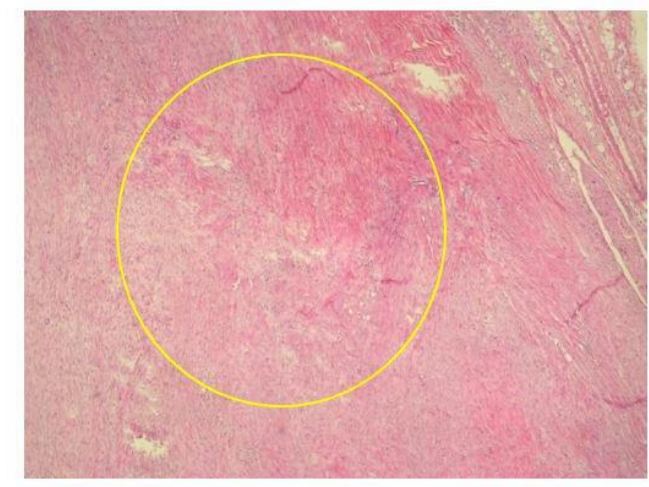

C

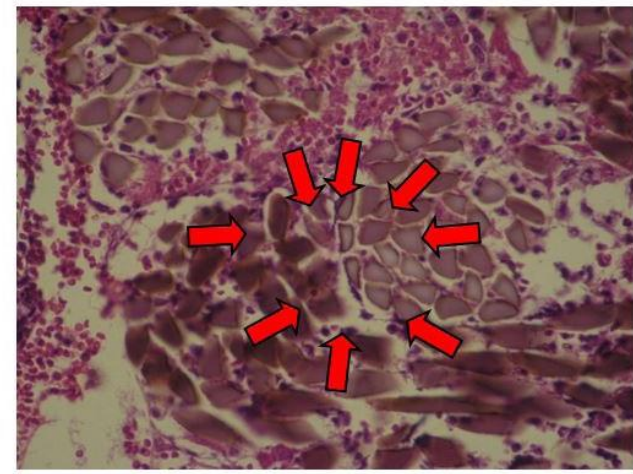

B

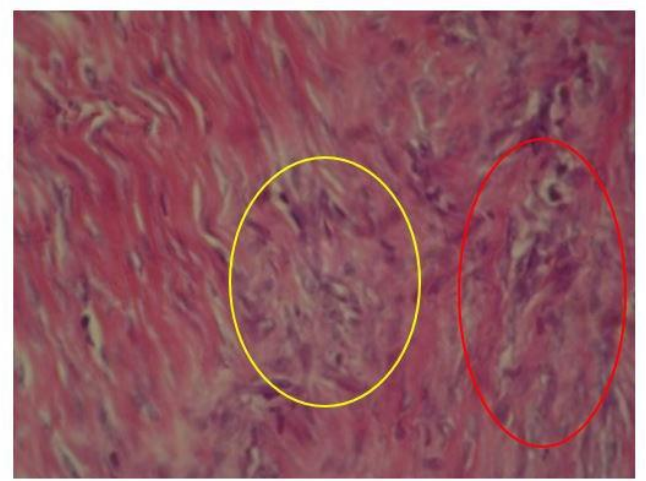

D

Figure 3: Acute inflammatory process throughout the tendon surface

Note: G2 (control group with 7 days lesion) and G3 (Magneto 7 days) - A: Tendon with Acute Inflammatory Response, presence of granulation tissue (Longitudinal Photomicrography, 40x, HE). B: Tendon with acute inflammatory response, presence of granulation tissue, polymorphonucleated cells (Longitudinal Photomicrograph, 400x, HE). C: Tendon with fibrosis and moderate chronic inflammatory response (Longitudinal Photomicrograph, 400x, HE). D: Tendon with advanced healing process with fibrosis (Longitudinal Photomicrograph, 40x, HE). 
observed, there is a greater organization of fibers, unlike the control (Photo A), in which a large effusion and fiber disruption is observed. By enlarging the image by $400 x$ (Foto D), the process of fiber regeneration and reorganization is better visualized, even with fibrosis, characterizing an advanced repair process.

In the Figure 4, Photo A, which represents a G - 4 sample (control with 14 days injury), shows an increased scar tissue, with presence of inflammatory process and a moderate amount of collagen tissue, i.e., presence of fibrosis. In Photo $B$, when the image is increased by $400 \mathrm{X}$, it is verified that the tissue is being repaired, but this healing occurs in a disorganized way, with a large presence of fibrosis. At 14 days of magnetotherapy treatment, illustrated in Photos C and D, there was a fully healed tendon tissue with organizing fibrosis without acute or chronic inflammation.

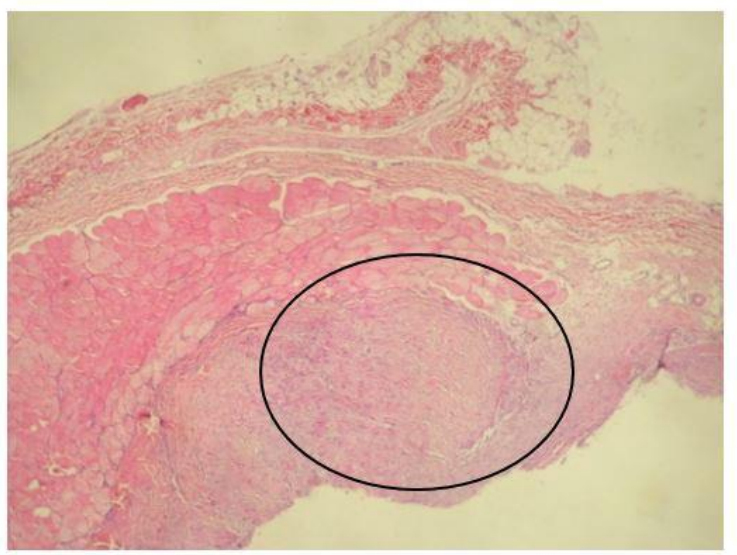

A

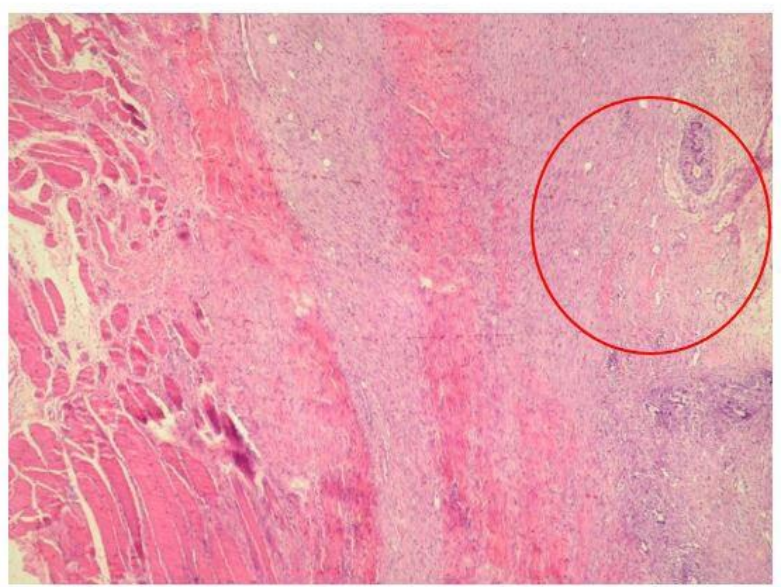

C

\section{DISCUSSION}

In the present study, it was observed that magnetotherapy reduced inflammation, accelerating the process of tissue repair. The group that received 5 applications had less acute inflammation when compared to its control and the group that received 12 applications had no inflammatory process, whereas its control had chronic inflammation. Tendon tissue regeneration can be divided into three sequential phases called: inflammatory, which occurs immediately after injury; proliferative or fibroblast begins approximately on the fifth day; and remodeling, begins in approximately four to eight weeks. Thus, with the use of magnetotherapy in the tendon injury, an acceleration of the fiber repair process can be observed ${ }^{(6)}$. A study involving six horses with traumatic tendinitis induced in the superficial digital flexor tendons of the right thoracic

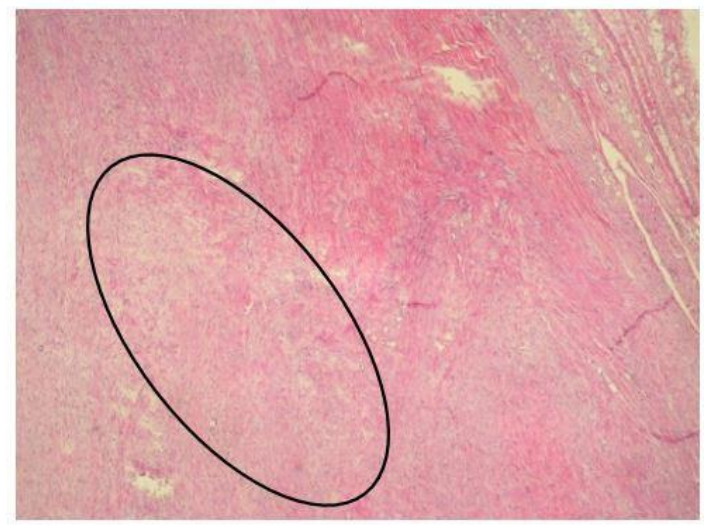

B

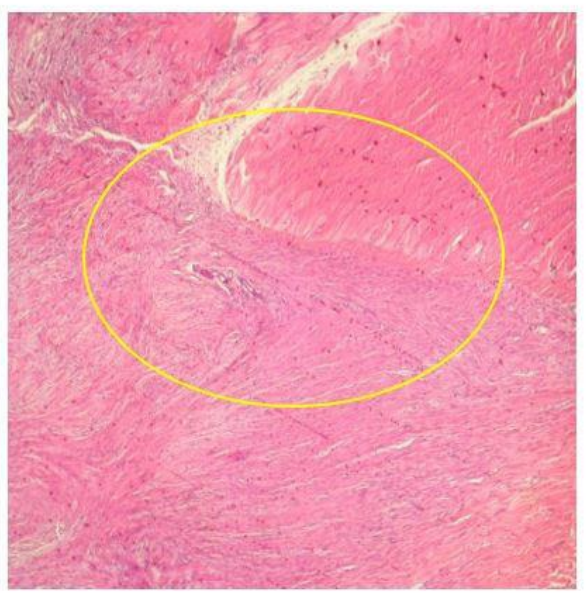

D

Figure 4: Scar tissue, with presence of inflammatory process and a moderate amount of collagen tissue and fibrosis process.

Note: G4 (control group with lesion - 14 days) and G5 (Magneto - 14 days) A: Increased Scar tissue, fibrosis and chronic inflammation (Longitudinal Photomicrograph, 100x, HE). B: Increased Scar tissue, fibrosis and chronic inflammation (Longitudinal Photomicrograph, 400x, HE). C: Advanced healing process with fibrosis (Longitudinal Photomicrograph, 400x, HE). D: Complete healing of tendon tissue (Longitudinal Photomicrograph, 400x, HE). 
$\operatorname{limb}$ found that the circumference of the $\operatorname{limb}$ treated with PMEF compared to the control up to 30 days was smaller. In the research we used a field intensity of 24 Gauss, frequency of 60 Hertz, one hour sessions duration, treatment frequency five times a week and 30 days treatment duration. The author mentions that these results are due to the anti-inflammatory action of the magnetic fields. This finding corroborates the research result, since in the group treated with 5 applications, the inflammatory process was smaller when compared to the control group, which presented acute inflammation and large edema in the lesion region ${ }^{(10)}$.

The anti-inflammatory effect of magnetotherapy occurs due to the magnetic and / or electromagnetic field, regardless of any heat produced by the fields themselves, probably eventually changing the cell membrane potential and thus influencing the ionic fluxes ${ }^{(9)}$. Magnetotherapy accelerates tissue regeneration, as the pulsatile electromagnetic field induces the formation of new electromagnetic fields perpendicular to their incidence area, promotes particle deviation with moving electric charges, normalizes membrane potential and stimulates cell metabolism ${ }^{(8)}$. Magnetic field therapy accelerates injury regeneration as it assists in extracellular matrix oxygenation and substrate cleansing, thereby decreasing the inflammatory process, increasing blood flow and the ability of cells to remove toxins ${ }^{(11)}$. According to LEE (1997), it was observed that the groups receiving the magnetotherapy treatment had less fibrosis formation and better collagen fiber organization and with 14 days of treatment the tendon was fully regenerated, unlike the two control groups that had increased fibrosis and disorganized fibers. This result is similar to the findings of another study ${ }^{(12)}$ in which treated 180 rats with Achilles Tendonitis using magnetotherapy, with parameters of 49.5 Gauss field strength and $46 \mathrm{~Hz}$ frequency. In this study the tendon returned to histological normality, showed no detectable inflammation and presented better collagen alignment until the end of the study (14 days). The author mentions that PEMF favors the production of collagen, since it has an intimate effect with the increase of fibroblast cell activity, with an improvement in the healing process when compared to the control groups with injury.

The PEMF favors a rapid reduction of the acute inflammatory process, as well as acceleration of the chronic phase with rapid tissue recovery process and stimulation of fibroblasts due to the increased kinetic and ionic activity of the therapeutic process ${ }^{(13)}$. The magnetic field acts mainly on the circulatory system, allowing an increase in blood flow, vasodilation and neovascular formation in the applied tissue, providing an increase in the local immune system input, as well as improving tissue tropism ${ }^{(14)}$. The PEMF generates an increase in blood flow in the applied tissue, as well as concentration of inflammatory cells favoring biological changes in the application region. These data clarify the findings of the study, which showed decreased inflammation and accelerated tissue repair in the group treated with PEMF when compared to the control group ${ }^{(15)}$. In the study of Santos ${ }^{(10)}$ that analyzed the tendon injury of the horses, through US, which after 22 days of treatment with magnetotherapy, the treated tendon presented grade II lesion while the control presented grade III. This confirms that the electromagnetic field accelerates the repair of the injured tendon, as verified in the present study. Magnetotherapy promotes inflammation reduction, accelerating the tissue repair process and favors the organization of collagen fibers, according to tension lines, without formation of fibrosis. Studies show that magnetic field therapy has been used in several areas of tissue repair, such as skin, muscle and bone injuries ${ }^{(16-19)}$. Thus, this feature decreases the regeneration time of the lesions and the patients returns to their activities earlier. Among the limitations of this study we highlight the absence of instruments that could better quantify the results. It is suggested for a better quantification of the obtained results, as well as the use of other parameters and injury models for tendinopathy, besides the application of magnetotherapy in humans.

\section{CONCLUSION}

Given the process of treating the Achilles tendon injury with the PEMF, it can be concluded that: magnetotherapy decreases the signs of inflammation in the acute phase, accelerates the repair process by 7 days, but still presents fibrosis in this period, and 14 days presents a complete repair without chronic inflammation.

\section{AUTHORS' CONTRIBUTIONS:}

AGCG, RMVS, MAS, PFM: collections supervision, text verification, scientific review and orientation; RMVS, DAPB, LBL, ADF, IES: data collection, statistical analysis and scientific writing.

\section{CONFLICT OF INTEREST}

No conflict of interest.

\section{AUTHORS DETAILS}

2. Universidade Federal de Rio Grande do Norte (UFRN), Natal, RN Brasil. 3. Universidade Potiguar (UnP), Natal, Rio Grande do Norte, Brasil. 4. Universidade Potiguar (UnP), Natal, Rio Grande do Norte, Brasil.

5. Universidad Nacional de Cordoba, Cordoba, Argentina. 6. Universidade Potiguar (UnP), Natal, Rio Grande do Norte, Brasil.

\section{REFERENCES}

1. Rosa, Rubens dos Santos. Efeito sinérgico da Associação Exercício/ Aquecimento nas propriedades Mecânicas e Estruturais do Tendão calcâneo. 2014. Tese (Doutorado em Bioengenharia) - Área Interunidades em Bioengenharia, Universidade de São Paulo, São Carlos.

2. Hespanhol Junior, Luis Carlos; Lopes, Alexandre Dias. Reabilitação das principais lesões relacionadas a corrida. Revista CES Movimento y Salud. 2013; 1, 1: 1-28.

3. Thompson, J.; Baravarian, B. Acute and Chronic Achilles Tendon ruptures in Athletes. Clin Podiatr Med Surg. 2011; 28: 117-35. 
4. Thomopoulos S, Parks WC, Rifkin DB, Derwin KA. Mechanisms of tendon injury and repair. J Orthop Res. 2015 Jun;33(6):832-9.

5. Zink, FLGA, Mendonça DG, Bittar CK, Zabeu JLA, Salomão O, Carvalho Júnior $A E$ et al. Use of the semitendinosus tendon for foot and ankle tendon reconstructions. rev bras ortop. 2014;49(5): 528-531

6. Duek JR, Riquetto ML, Jesus DC, Sabongi Neto JJ, Barbo MLP, Duek EAR et al. Membrana de PLDLA-TMC como Protetor na Regeneração do Tendão Calcâneo. Estudo in Vivo em Coelhos. Polímeros [online]. 2014; 24, 3: 360-66.

7. Meyer PF, Cavalcanti APS, Silva EM, Silva RMV, Costa LS, Ronzio OA Magnetoterapia: é possível este recurso fazer parte da rotina do fisioterapeuta brasileiro? Arquivos Brasileiros de Ciências da Saúde. 2011; 36, 1, 35-39.

8. Zaragoza, Juan Ramón. Física e intrumentacion medicas: instrumentación diagnóstica, instrumentación de la imagen, instrumentación terapéutica. 2 ed, Barcelona: Ediciones cientificas y técnicas, 1992.

9. Tiktnsky, R.; Chen, L.; Narayan, P. Electrotherapy: yesterday, today and tomorrow. Haemophilia. 2010 Jul;16 Suppl 5:126-31.

10. Santos, Margareth Carvalho. O Uso de Campos Eletromagnéticos Pulsáteis no Tratamento de Tendinite Traumática Induzida do Flexor Digital Superficial do Membro Torácico do Eqüino. 2000. Tese (Mestrado em Ciências Veterinárias) -Universidade Federal do Paraná, Curitiba.

11. Cardentey GJ, González GX, Porras MO Effectiveness of magnet therapy in the treatment of alveolitis AMC 2016; 20 (4): 386-93
12. Lee, Edwin Wai Chi. Pulsed magnetic and electromagnetic fields in experimental achilles tendonitis in the rat: a prospective randomized study. Arch Phys Med Rehabil. 1997 Apr;78(4):399-404.

13. Espinosa Álvarez RF, Montero García, JL, Novoa Blanco, JF. Tratamiento magnético de los traumatismos no complicados. Reportes preliminares. Rev Cubana Med Gen Integr. 2007;23(4):1-6.

14. Laakso L, Lutter F, Young C. Static magnets: what are they and what do they do?. Rev. bras. fisioter. [Internet]. 2009 Feb [cited 2019 Oct 26] ; 13(1): 10-23.

15. Fernandez, MI, Watson, PJ, Rowbotham, DJ. Effect of pulsed magnetic field therapy on pain reported by human volunteers in a laboratory model of acute pain. Br J Anaesth. 2007 Aug;99(2):266-9.

16. Hidalgo de Paz Armando, González Deben Marta, Quiñonez Ceballos Alfredo. Acción del campo magnético de baja frecuencia en la cicatrización de la piel. Rev Cubana Invest Bioméd [Internet]. 2001 Sep [citado 2019 Oct 26] ; 20(3): 178-183.

17. Caierão, QM, Teodor, RM, Minamoto, VB. A Influência Da Imobilização Sobre o Tecido Conjuntivo Muscular: Uma Revisão. Fisioterapia em Movimento. 2007 20(3): 87-92.

18. Schmidt-Rohlfing B, Silny J, Gavenis K, Heussen N. Elektromagnetische Felder, elektrischer Strom und Knochenheilung: was ist gesichert? Z Orthop Unfall 2011; 149(3): 265-270

19. Kortekaas R, van Nierop LE, Baas VG, Konopka KH, Harbers M, van der Hoeven JH et al. A Novel Magnetic Stimulator Increases Experimental Pain Tolerance in Healthy Volunteers - A Double-Blind Sham-Controlled Crossover Study. PLoS One. 2013 Apr 19;8(4):e61926. 